\title{
Influence of alternative conifer release treatments on soil nutrient movement
}

\author{
by J.A. Simpson ${ }^{1}$, A.M. Gordon ${ }^{1}$, P.E. Reynolds ${ }^{2}$, R.A. Lautenschlager ${ }^{3}$, F.W. Bell ${ }^{3}$, D. Gresch ${ }^{1}$ \\ and D. Buckley ${ }^{2}$
}

\begin{abstract}
Zero tension soil solution samplers were used to collect soil solution at $75 \mathrm{~cm}$ for one and one-half years after the following treatments: 1) helicopter applied Release ${ }^{\circledR}$ silvicultural herbicide (a.e. triclopyr@1.9 kg a.e. ha ${ }^{-1}$ ), and 2) helicopter applied Vision ${ }^{\circledR}$ silvicultural herbicide (a.e. glyphosate@1.5 kg a.e. ha ${ }^{-1}$ ); 3) motor-manual cutting (brush saws); and 4) control (no treatment). Results show no substantial treatment related differences in the movement of selected nutrients (total organic $\mathrm{N}, \mathrm{NH}_{4}^{+}, \mathrm{NO}_{3}^{-}$; $\mathrm{K}, \mathrm{Ca}$ ) among these treatments. Mean nitrate concentration was less than $1.5 \mu \mathrm{g} \mathrm{mL}^{-1}$ throughout the sampling period and was marginally higher, but not statistically different, following release treatments.
\end{abstract}

Key words: alternative conifer release treatments, brushcutting, calcium, ecosystem research, Fallingsnow Ecosystem Project, glyphosate, herbicides, nutrients, nitrogen, potassium, soil solution, tending, triclopyr, vegetation management
On a effectué la prise d'échantillons de sol à $75 \mathrm{~cm}$ de profondeur sous forme de solution à une tension égale à zéro un an et un an et demi après les traitements suivant: 1) une pulvérisation de phytocide sylvicole Release ${ }^{\circledR}$ effectuée à partir d'un hélicoptère (élément actif triclopyr@1.9 kg é.a. ha ${ }^{-1}$ ), une pulvérisation de phytocide sylvicole Vision ${ }^{\circledR}$ effectuée à partir d'un hélicoptère (élément actif glyphosate @ $1.5 \mathrm{~kg}$ é.a. ha ${ }^{-1}$ ); 3) un dégagement manuel motorisé (scics débroussailleuses); et 4) un témoin (pas de traitement). Les résultats démontrent aucune différence substantielle reliée au traitement sur le déplacement de certains éléments nutritifs ( $\mathrm{N}$ total organique, $\mathrm{NH}_{4}{ }^{+}, \mathrm{NO}_{3}-\mathrm{K}, \mathrm{Ca}$ ) à la suite de ces traitements. La concentration moyenne de nitrate était de moins de $1.5 \mu \mathrm{g} \mathrm{mL}-1$ au cours de toute la période d'échantillonnage, et était supérieure de façon marginale, mais sans être statistiquement différente, suite aux traitements de dégagement.

Mots clés: traitements alternatifs de dégagement des conifères, débroussaillage, calcium, recherche écosystémique, projet écosystémique de Fallingsnow, glyphosate, phytocide, éléments nutritifs, azote, potassium, solution de sol, soins culturaux, triclopyr, contrôle de la végétation

\section{Introduction}

The use of conifer release to increase conifer production is common across a variety of North American forest ecosystems (Walstad and Kuch 1987). Since the publication of results from studies which examined the effects of forest disturbance on biogeochemical processes at Hubbard Brook (Bormann and Likens 1979), concern has been expressed about operational conifer release with herbicides. One particular concern is that this treatment may lead to significant loss of soil nutrient capital because herbicides reduce densities of non-crop plants assumed to retain otherwise mobile nutrients on site. Few studies, however, have attempted to document the effects of operational release treatments on soil solution dynamics, or potential nutrient losses.

In Maine, Smith et al. (1986) showed that approximately one year after whole-tree harvest, maximum concentrations of soil solution nitrate, collected from tension lysimeters at a depth of $25 \mathrm{~cm}$, approached $80 \mathrm{mg} \mathrm{L}^{-1}$ on moderately well-drained soils. Subsequently, Smith et al. (1988) examined the effects of operational application of herbicide solutions which contained triclopyr on watershed nutrient dynamics and streamwater

\footnotetext{
${ }^{1}$ Department of Environmental Biology, University of Guelph, Guelph, Ontario, Canada N1G 2W1.

${ }^{2}$ Canadian Forest Service-Sault Ste. Marie, P.O. Box 490, 1219 Queen St. E., Sault Ste. Marie, Ontario, Canada P6A 5M7.

${ }^{3}$ Ontario Forest Research Institute, P.O. Box 969, 1235 Queen St. E., Sault Ste. Marie, Ontario, Canada P6A 5N5.
}

losses from the treated system. Following harvest, the site was allowed to naturally regenerate for four years before being treated. Approximately one year after herbicide application, soil solution nitrate levels approached $50 \mathrm{mg} \mathrm{L}^{-1}$, although streamwater concentrations within the watershed remained below $10 \mathrm{mg} \mathrm{L}^{-1}$. The authors report a strong seasonal trend in nitrate concentrations and suggest that this result was due to the two major factors that control nitrification - soil nitrification potential and reduction in vegetative cover. Additionally, concentrations of nitrate on somewhat poorly and poorly drained soils were much less than that under well drained conditions. This was attributed to a reduced potential for nitrification.

Increases in nitrate have also been observed in streamwaters fed by treated watersheds. Likens et al. $(1969,1978)$ "cut in place" (no material removed from the site) a small watershed within the Hubbard Brook forest reserve and inhibited revegetation with repeated herbicide application. Likens et al. (1969) reported an increase in streamwater nitrate from a pretreatment annual average of $0.9 \mathrm{mg} \mathrm{L}^{-1}$ to $53 \mathrm{mg} \mathrm{L}^{-1}$ two years after herbicide applications were concluded. This large increase can be attributed to the removal of vegetation that would otherwise have a high demand for this nutrient coupled with increased rates of nitrification and run-off. Under conditions that reflect more typical management systems, $\mathrm{NO}_{3}$ - losses have also been observed. $\mathrm{NO}_{3}{ }^{-}$increases were reported by Neary et al. (1986) from a herbicide treated watershed in Georgia (maximum $\mathrm{NO}_{3}{ }^{-} \sim 5 \mathrm{mg}$ $\mathrm{L}^{-1}$ ), by Vitousek and Matson (1985) in North Carolina (maximum $\mathrm{NO}_{3}^{-} \sim 8 \mathrm{mg} \mathrm{L}^{-1}$ ) and by Kimmins et al. (1987) in British 
Columbia (maximum $\mathrm{NO}_{3}^{-} \sim 10.5 \mathrm{mg} \mathrm{L}^{-1}$ ). Kimmins et al. (1987) further suggest that disturbance due to harvesting results in greater nutrient loss than competition control.

Along with increases in $\mathrm{NO}_{3}{ }^{-}$, other nutrients may also be lost from disturbed forest ecosystems. Neary et al. (1986) observed a $41 \%$ increase in $\mathrm{Mg}^{+2}$ and a $30 \%$ increase in both $\mathrm{K}^{+}$and $\mathrm{Ca}^{+2}$ in streamwater following site preparation with the herbicide hexazinone. Both Neary et al. (1986) and Bormann and Likens (1979) indicate that the pattern of cation loss from a disturbed ecosystem closely follows that of $\mathrm{NO}_{3}{ }^{-}$. Neary et al. (1986) suggest that the increase in soluble cations in streamwater was the result of mass balance, the high cation charge required to balance a four-fold increase in $\mathrm{NO}_{3}{ }^{-}$found in stream waters.

Changes in nutrient fluxes through a deforested ecosystem are generally rapid and significant. In the Hubbard Brook study (Likens et al. 1978), nutrient concentration in streamwater peaked two years after cutting, although many of the measured biogeochemical parameters approached pretreatment levels three to four years after cutting, or coincided with revegetation following the herbicide treatments. This indicates a high potential for biotic recovery (resilience) in disturbed northern hardwood ecosystems. This relatively rapid rate of recovery is similar to results observed by others (Mann et al. 1988; Neary et al. 1986). Likens et al. (1978), however, indicated that recovery of the nutrients lost from the Hubbard Brook watershed may take upwards of 80 years. In the boreal forest of northern Ontario, this process may take considerably longer as biogeochemical weathering is generally slower than that of more temperate climates and the underlying Precambrian bedrock is generally nutrient poor.

Most of the current literature discusses nutrient movement as a result of major disturbance, primarily harvesting. From this, one can hypothesize about the effects of a relatively minor disturbance, such as competition control, on the movement of nutrients. Additionally, there has been little related boreal ecosystem research, although Van Cleve et al. (1993a) provide an overview of primary succession studies in the boreal forest of interior Alaska, one of the few comprehensive studies of boreal ecosystem processes. Van Cleve et al. (1993b) determined that nitrification was at a maximum early in succession with nitrate accounting for $98 \%$ of the mineralized $N$ under young poplar-alder (Populus balsamifera L. - Alnus incana [L.] Moench spp. tenuifolia [Nutt.] Breit.) forest cover. In mid and late succession within the poplar and spruce forest, nitrate accounted for less than $4 \%$ mineral $\mathrm{N}$ in the forest floor. The practical implication of this is that, where clay minerals are present, $\mathrm{NH}_{4}{ }^{+}$is rapidly fixed and subsequent release is dependent on the clay weathering rate. Nitrate, however, is held on the scarce soil anion exchange surfaces. Dissolved $\mathrm{NO}_{3}{ }^{-}$must, therefore, either be taken up by plants or immobilized; otherwise, it will be lost through leaching and denitrification. While ammonium may be conserved, high rates of nitrification may ultimately result in high $\mathrm{N}$ losses from the site, especially after harvesting (Gordon and Van Cleve 1983).

The Fallingsnow Ecosystem Project (Lautenschlager et al. 1997) provided the opportunity to examine the consequences of operational conifer release using two different herbicides

\footnotetext{
${ }^{1}$ Trademark of Monsanto.

${ }^{2}$ Trademark of DowElanco.
}

(Vision ${ }^{\circledR 1}$ (a.i. glyphosate) and Release ${ }^{\circledR 2}$ (a.i. triclopyr) on deep leaching and potential loss from the system of selected nutrients in the soil solution, and to compare that with changes associated with a commonly proposed alternative to herbicides (motormanual treatment with brush saws).

\section{Methods}

The study area is approximately $60 \mathrm{~km}$ south-west of Thunder Bay, Ontario, and is part of the Great Lakes-St. Lawrence Forest Region (Rowe 1972). The study used a randomized complete block design with four blocks ( 28 to 52 ha in size) and the following treatments: 1) motor-manual release with brush saws (mid to late October 1993); 2) mechanical release with the Silvana Selective/Ford Versatile (late October to early November 1993); 3) aerially applied Release ${ }^{\circledR}$ silvicultural herbicide (1.9 kg a.e. triclopyr ha-1, mid-August, 1993); 4) aerially applied Vision ${ }^{\circledR}$ silvicultural herbicide $(1.5 \mathrm{~kg}$ a.e. glyphosate $\mathrm{ha}^{-1}$; mid-August, 1993); and 5) control (no treatment). Blocks were harvested and then planted with bareroot stock of either black spruce (Picea mariana (Mill.) B.S.P.) (block one) or white spruce ( $P$. glauca (Moench) Voss) (blocks two - four) between 1987 and 1991. (See Bell et al., [1997a,b] this volume) for additional information about the study area and treatments).

Nutrient changes following the mechanical (Silvana Selective/Ford Versatile) treatment are not documented in this study; and, we examined changes on blocks one, three and four only as block two was inaccessible at the time this study was initiated.

Blocks, and plots within blocks, vary in elevation and topography. The soils are predominately imperfectly drained silt loam. However, textures range from very fine sandy loam to silty clay and drainage ranges from very dry (shallow to bedrock) to poorly drained organic soils. Every attempt was made to instrument the variable conditions within each treatment; however, extreme site conditions, not representative of the treatment area as a whole, were not instrumented.

Zero tension solution samplers were employed in this study. The design of these samplers is flexible, such that suction may be applied if necessary. However, for the purpose of sampling for leached solutes, zero tension sampling is preferred (Magid and Christensen 1993). The body of the samplers are 12-mm PVC plastic tubing fitted with a porous ceramic cup, one bar air entry value (model 655X01-B1M3, Soil Moisture Corp., Santa Barbara, California), on one end and a rubber stopper on the other. Spaghetti tubing is inserted through the stopper such that it extends to the bottom of the ceramic cup. A second piece of tubing is inserted several centimetres into the chamber to allow pressure equalization. This design is relatively inexpensive, easily repaired in the field and allows for rapid sampling.

Fifteen samplers were installed in groups of three to a depth of $75 \mathrm{~cm}$ at each of five locations in each treatment area. Holes were drilled at $45^{\circ}$ angle into the soil and a slurry, made of excavated soil and deionized water, was poured into the hole. Samplers were then installed. The slurry was used to ensure that the ceramic cups were in direct contact with the soil. Samplers were placed in the rows where spruce were planted and at a constant depth relative to the rooting zone of the crop trees. Samples were collected approximately every two weeks.

Soil solution samples were collected through vacuum displacement. Where little or no sample was collected passively, tension (approximately $1 / 3$ bar) was applied for a short period of time. In several cases, especially during the summer, no 

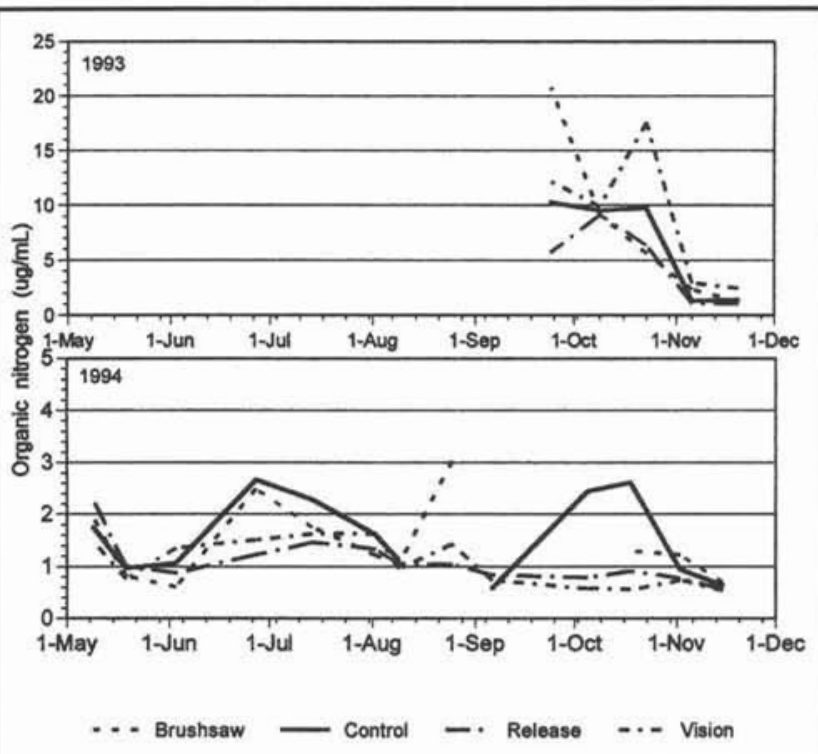

Fig. 1. Seasonal pattern of mean organic nitrogen concentration sampled from a depth of $75 \mathrm{~cm}$.

sample could be retrieved. For example, extended dry periods in 1994 reduced the number and amount of samples collected. This was attributed to site conditions rather than equipment failure. Samples were chilled on site and frozen as soon as possible after collection.

Samples from the individual samplers were analysed separately for ammonium, nitrate, total Kjeldahl nitrogen (Technicon II Auto Analzyer), calcium and potassium (U.S.E.P.A. method No. 200.2). Total organic nitrogen (ON) was calculated by subtracting values for ammonium and nitrate from total Kjeldahl nitrogen. Samples from a group of samplers were bulked for analysis if insufficient sample was available for individual analyses. The soil solution samples collected were free of any particulate matter or other contamination and were analysed without any additional pre-treatment such as filtration.

SAS (SAS Institute 1988) and SPSS/w (SPSS Inc. 1994) were used for all statistical analysis. A repeated measures analysis that employs univariate statistics to evaluate response curves (Meredith and Stehman 1991) was used to analyze the soil solution chemistry data. This method depends on the ability to fit an equation that describes the data over time as a general form for each sub-group. For this study, data was divided into groups of treatments within blocks. For each of the five sample locations within a treatment, nutrient concentrations were averaged and $\log$ transformed providing a distribution of residual error that closely approximated a normal distribution. Parameter estimates of each equation were compared using standard ANOVA techniques.

\section{Results}

Mean organic nitrogen $(\mathrm{ON})$ concentrations in the fall of 1993 , immediately after installation of the samplers, show a sharp increase (Fig. 1). This is most likely due to organic matter falling into the hole at the time of installation which would result in high concentrations of $\mathrm{N}$ species $\left(\mathrm{NO}_{3}{ }^{-} ; \mathrm{NH}_{4}{ }^{+}\right.$, soluble organic $\left.\mathrm{N}\right)$. However, these values quickly fell to expected levels. In 1994 , ON concentrations increased during the spring and gradually declined through the summer and fall. Throughout

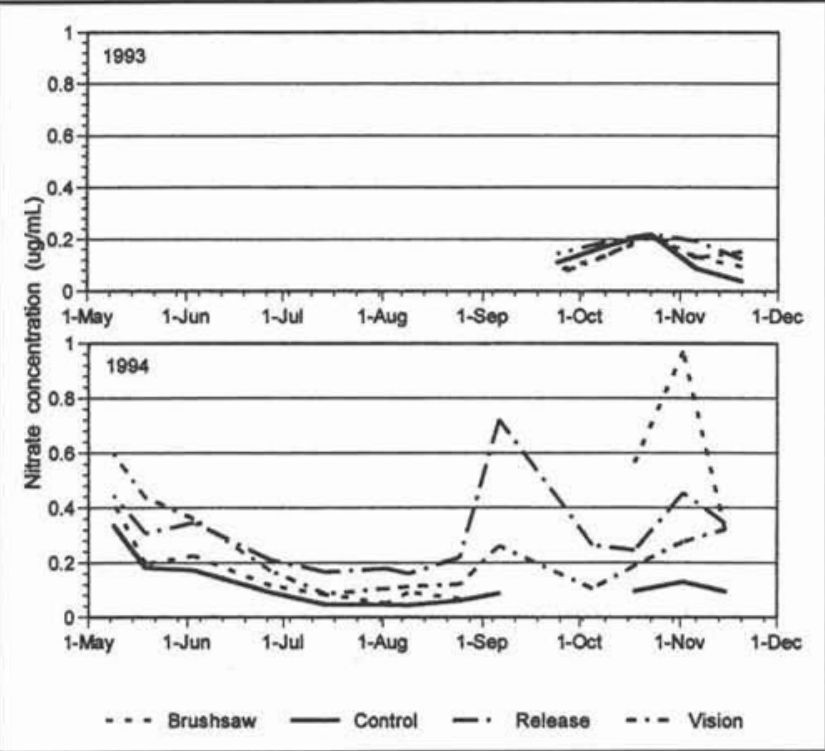

Fig. 2. Seasonal pattern of mean nitrate nitrogen concentration sampled from a depth of $75 \mathrm{~cm}$.

1994 ON concentrations are within expected ranges with a maximum mean concentration of slightly less than $3 \mu \mathrm{g} \mathrm{mL}^{-1}$. No significant difference was observed among treatments.

Nitrate concentrations follow a simple pattern (Fig. 2). All treatments exhibited remarkably similar responses in 1993. There is a general reduction in free nitrate throughout the 1994 growing season with a subsequent increase beginning in September. The two herbicide treatments exhibited slightly higher, but not statistically different, concentrations throughout most of the growing season; however, concentrations remain very low, less than $1.0 \mu \mathrm{g} \mathrm{mL}^{-1}$. Ammonium levels in the soil solution are universally low, typically less than $0.2 \mu \mathrm{g} \mathrm{mL}^{-1}$, and no treatment differences were detected.

Solution calcium concentration (Fig. 3) exhibits a general increasing trend over the sampling season in 1994. In 1994, concentrations typically ranged from 10 to $35 \mu \mathrm{g} \mathrm{mL}^{-1}$, except for the control treatment, late in the season. This is similar to the control treatment response found in the fall of 1993. Potassium concentrations in the sampled solution (Fig. 4) showed a generally declining trend through the summer and fall. However, there was a marked increase in potassium concentrations at the beginning of November, 1994. Maximum mean concentrations never exceeded $2.5 \mu \mathrm{g} \mathrm{mL}-1$.

\section{Discussion}

Under field conditions, it is virtually impossible to eliminate all contamination. This is reflected in the 1993 data where the highest concentrations of ON were observed. Results from 1994 follow a more predictable pattern with the herbicide treatments following a parallel pathway and the motor-manual and control treatments exhibiting parallel paths that diverge from the herbicide treatments in late June and mid September (Fig. 1). Although the herbicide and non-herbicide treatments alternately diverge and converge, there was no overall statistical difference between treatments. Concentrations of nitrogen species were within expected ranges and were comparable to other studies (e.g. Neary et al. 1986); however, differences between the control and treated areas were less than expected. 


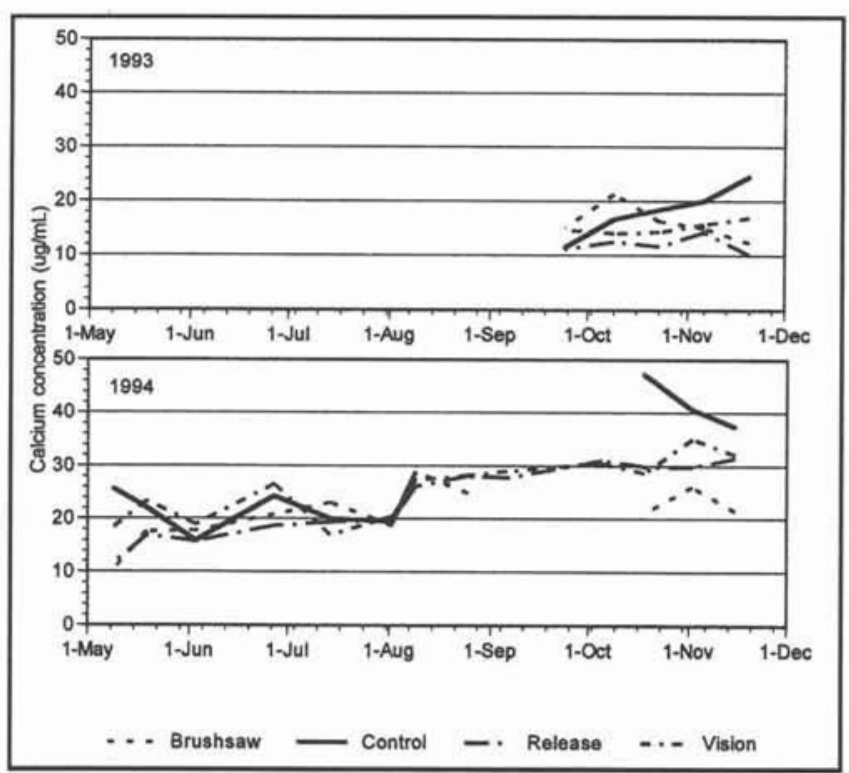

Fig. 3. Seasonal pattern of mean calcium concentration sampled from a depth of $75 \mathrm{~cm}$.

This study provides some evidence that herbicide treated sites can exhibit enhanced rates of mineralization as can be seen in the patterns of $\mathrm{ON}$ (Fig. 1) and $\mathrm{NO}_{3}^{-}$(Fig. 2) concentrations. $\mathrm{NO}_{3}{ }^{-}$concentrations under the herbicide treatments are generally higher than the control and motor-manual treatments. The reverse is typically true of the $\mathrm{ON}$ concentration, although the magnitude of the difference is greater here. Enhanced mineralization is likely due to improved microclimatic conditions caused by a reduction in vegetative cover along with the addition of organic substrate and/or enhanced microbial activity. The magnitude of the increase of $\mathrm{NO}_{3}{ }^{-}$concentration is less than expected, an indication of the rapid recovery of the treated areas. At this time it is unclear whether nutrient uptake under the herbicide treatments can be attributed to the crop trees or the regeneration of competing species.

Presently, there are insufficient data to conclusively describe the cause-effect relationship between treatments and calcium mobility. However, the lack of treatment differences and almost linear increase in calcium concentration from the initiation of the study would suggest that the observed trends are the result of natural pedogenic processes. In the short-term, at least, these processes appear to be insensitive to the competition control treatments and likely reflect a response to previous disturbances. Increasing potassium content in the sampled solution late in the season may be due to release of potassium from dying annuals and leaching from abscised deciduous vegetation and do not appear to be a result of the release treatments. In all cases, the concentration of potassium did not exceed $3 \mu \mathrm{g}$ $\mathrm{mL}^{-1}$. At such low concentrations treatment effects may be masked by biogeochemical weathering of soil minerals and bedrock as well as atmospheric inputs.

Another consequence of competition control is the change in microclimate and subsequent changes in decomposition rates. Temperature of exposed litter may be 9 to $10^{\circ} \mathrm{C}$ higher than that found under a closed forest canopy (Stone 1973). Reynolds et al. (1997) observed significant increases in surface temperature after herbicide treatment, but not under mechanical/manual treatments, at the Fallingsnow site (Lautenschlager et al. 1997).

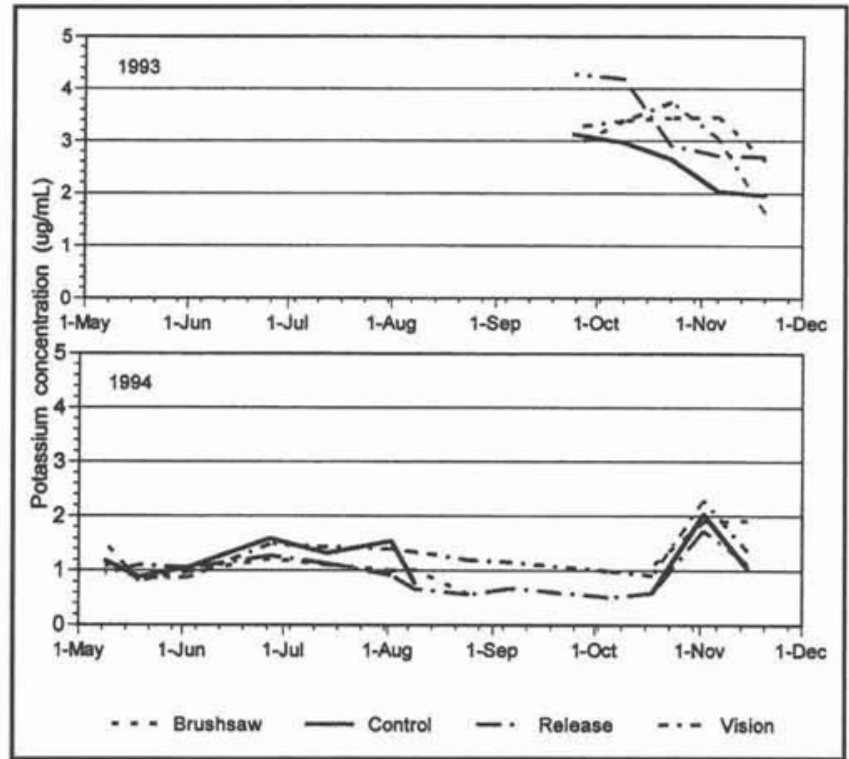

Fig. 4. Seasonal pattern of mean potassium concentration sampled from a depth of $75 \mathrm{~cm}$.

Changes in temperature and soil moisture can significantly affect the activity of microbial and insect populations resulting in changes in the rate of nutrient release (mineralization) from the organic pool. Harcombe (1975), working in Costa Rica, further suggests that microclimate changes, specifically those affecting soil moisture and temperature, may have a greater influence on the reduction of nutrient losses from early successional forests than the re-establishment of plant uptake mechanisms.

\section{Conclusion}

Definitive conclusions are not yet possible. Treatment effects are difficult to detect due to large variances in the data. However, to date, there does not appear to be a significant treatment effect by any of the competition control practices. This may, in part, be due to the rapid recovery of vegetation after treatment. Our results were similar to those of Smith et al. (1988) where little treatment differences existed under poorly and somewhat poorly drained site conditions. As much of the Fallingsnow research area falls into one of these two categories, primarily imperfectly drained (assumed to be equivalent to the previous authors "somewhat poorly drained" description) it is not surprising that larger treatment differences were not observed.

Under the motor-manual control practice, or any other manual/mechanical control, woody competition, such as aspen, would be left to rot on the ground. However, for this to occur, the material must make intimate contact with the soil and requires some form of compaction. In the boreal forest this will occur through time from snow compaction and trampling by wildlife. As this carbon rich substrate begins to decompose, many nutrients, most importantly nitrogen, will be temporarily immobilized through microbial activity. Gorham et al. (1979) suggest that this process may limit losses from disturbed ecosystems. To date, visual observation of the study area does not suggest that decomposition of woody material is proceeding at a significant rate and, as such, this process has not yet been observed. Gorham et al. (1979) further suggest that pioneer species in secondary succession may limit nutrient loss 
from whole ecosystems as the biomass of pioneer species increases. After the competition control treatments applied in this study were completed in the fall of 1993, the treated areas were rapidly reoccupied by such species, although of differing composition, depending on the treatment (Bell et al. 1997a).

\section{Acknowledgments}

This project was funded by the Agriculture Research Institute of Ontario and supported by the Vegetation Management Alternatives Program (VMAP) under the Sustainable Forestry Initiative of the Ontario Ministry of Natural Resources. Thanks to T. Baxter and T. Bohn for their technical assistance and W. Mathes-Sears for statistical advice.

\section{References}

Bell, F.W., R.A. Lautenschlager, R. Wagner, D.G. Pitt, W.J. Hawkins and K.R. Ride. 1997. Motor-manual, mechanical, and herbicide release affect early successional vegetation in northwestern Ontario. For. Chron. 73: 61-68.

Bell, F.W., K.R. Ride, M. St-Amour and M. Ryans. 1997. Productivity, cost, efficacy and cost effectiveness of motor-manual, mechanical and herbicide release of boreal spruce plantations. For. Chron. 73: 39-46.

Bormann, F.H. and G.E. Likens. 1979. Pattern and process in a forested ecosystem. Springer-Verlag, New York, NY. 253 p.

Gordon, A.M. and K. Van Cleve. 1983. Seasonal patterns of nitrogen mineralization following harvesting in the white spruce forests of interior Alaska. Pp. 119-130. In: Resources and Dynamics of the Boreal Zone. Proc. Boreal Forest Symp., A.C.U.N.S., Ottawa, Ontario. 544 p.

Gorham, E., P.M. Vitousek and W.A. Reiners. 1979. The regulation of chemical budgets over the course of terrestrial ecosystem succession. Ann. Rev. Ecol. Syst. 10:53-84.

Harcombe, 1975. Nutrient accumulation by vegetation during the first year of recovery of a tropical forest ecosystem. pp. 347-378. In: Recovery and restoration of damaged ecosystems. J. Cairns, Jr., K.L. Dickson and E.E. Herricks (eds.) University Press of Virginia, Charlottesville. $531 \mathrm{p}$.

Kimmins, J.P., K.M. Tsze and R.E. Bigley. 1987. Development of non-commercial vegetation following clearcutting and clearcuttingplus-slashburning, and some biogeochemical effects of herbicidal control of this vegetation. In: Proceedings of the Carnation Creek Herbicide Workshop. P.E. Reynolds (ed.) FRDA Report, ISSN 0835-0752.

Lautenschlager, R.A., F.W. Bell, R.G. Wagner and J.A. Winters. 1997. The Fallingsnow Ecosystem Project: Comparing conifer release alternatives in northwestern Ontario. For. Chron. 35-38.

Likens, G.E., F.H. Bormann and N.M. Johnson. 1969. Nitrification: importance of nutrient losses from a cutover forested ecosystem. Science 163: 1205-1206.
Likens, G.E., F.H. Bormann, R.S. Pierce and W.A. Reiners. 1978. Recovery of a deforested ecosystem. Science 199: 492-496. Magid, J. and N. Christensen. 1993. Soil solution sampled with and without tension in arable and heathland soils. Soil Sci. Soc. Am. J. 57: 1463-1469.

Mann, L.K., D.W. Johnson, D.C. West, D.W. Cole, J.W. Hornbeck, C.W. Martin, H. Riekrik, C.T. Smith, W.T. Swank, L.M. Tritton and D.H. Lear. 1988. Effects of whole-tree and stem-only clearcutting on postharvest hydrologic losses, nutrient capital and regrowth. For. Sci. 2: 412-428.

Meredith, M.P. and S.V. Stehman. 1991. Repeated measures experiments in forestry: focus on analysis of response curves. Can. J. For. Res. 21: 957-965.

Neary, D.G., P.B. Bush and M.A. Grant. 1986. Water quality of ephemeral forest streams after site preparation with the herbicide hexazinone. For. Ecol. Manage., 14:23-40.

Reynolds, P.E., J.A. Simpson, R.A. Lautenschlager, F.W. Bell, A.M. Gordon, D.A. Buckley and D.A. Gresch. 1997. Alternative conifer release treatments affect below- and near-ground microclimate. For. Chron. 73: 75-82.

Rowe, J.S. 1972. Forest regions of Canada. Publ. no. 1300, Dept. of the Environment, Canadian Forest Service, Ottawa, Ontario. 172 p. SAS Institute Inc. 1988. SAS/STAT ${ }^{\circledR}$ Users Guide, Release 6.03 Ed. Cary, N.C.: SAS Institute Inc. 1028 p.

Smith, C.T., M.L. McCormack, J.W. Hornbeck and C.W. Martin. 1986. Nutrient and biomass removals from a red spruce-balsam fir whole-tree harvest. Can. J. For. Res. 16: 381-388.

Smith, C.T., J.W. Hornbeck and M.L. McCormack. 1988. Changes in nutrient cycling following aerial application of Triclopyr to release spruce-fir. Proc. NE. Weed Sci. Soc. 42:94-99.

SPSS Inc. 1994. SPSS v. 6.1/win. SPSS Inc., Chicago, IL.

Stone, E. 1973. The impact of timber harvest on soil and water. pp. 427-467. In: Report of the President's advisory panel on timber and the environment, Washington, D.C.: GPO.

Van Cleve, K., L.A. Viereck and G.M. Marion. 1993a. Introduction and overview of a study dealing with the role of salt-affected soils in primary succession on the Tanana River floodplain, interior Alaska. Can. J. For. Res. 23:879-888.

Van Cleve, K., J. Yarie, R. Erickson and C.T. Dyrness. 1993b. Nitrogen mineralization and nitrification in successional ecosystems on the Tanana River floodplain, interior Alaska. Can. J. For. Res. 23:970-978.

Vitousek, P.M. and P.A. Matson. 1985. Disturbance, nitrogen availability and nitrogen losses in an intensively managed loblolly pine plantation. Ecol. 66: 1360-1376.

Walstad, J.D. and P.J. Kuch. 1987. Forest vegetation management for conifer production. John Wiley and Sons. $523 \mathrm{p}$. 